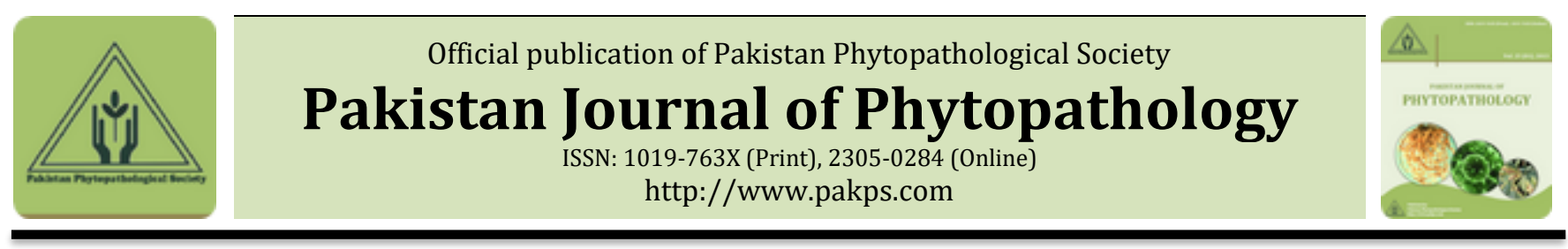

\title{
VIRULENCE CHARACTERIZATION OF LEAF RUST ISOLATES FROM 2017-18 WHEAT CROP OF SINDH PAKISTAN
}

\author{
aMuhammad Sufyan, aJaved I. Mirza, bMuhammad Saeed, cMuhammad R. Khan, aMuhammad Fayyaz, \\ aKhalil A. Khanzada, dShafi M. Khatti, eMuhammad I. Tahir \\ ${ }^{a}$ Crop Diseases Research Institute, PARC Substation Murree, Pakistan. \\ b Wheat Research Sub-Station Murree, Pakistan. \\ ${ }^{\mathrm{C}}$ International Maize and Wheat Improvement Center, Islamabad, Pakistan. \\ d Wheat Research Institute Sakrand, Sindh, Pakistan. \\ e Department of Plant Pathology, PMAS Arid Agriculture University, Rawalpindi, Pakistan.
}

\section{A B S T R A C T}

Wheat leaf rust disease, caused by Puccinia triticina poses severe threat to the $80 \%$ of the wheat cultivated across Pakistan. One hundred and twenty-nine leaf rust samples collected from Sindh during 2017-18 wheat cropping season were processed and eleven single uredinial isolates were revived and analyzed using North American set of differentials. Seven virulent profiles were found amongst these isolates. LKTSS was most common, found in four isolates; LKFJS was identified in two isolates. MKPSS, LKFKS, PKKSS and LKHSS were identified in single isolate only. Virulence was absent for $L r 2 \mathrm{a}, \operatorname{Lr} 9, \operatorname{Lr} 19, \operatorname{Lr} 27+31$ and $L r 28$. Whereas only a single isolate PKKSS was virulent to $L r 2 \mathrm{c}$ and isolate LKFKS to $\operatorname{Lr} 18$. Virulence for the leaf rust genes $\operatorname{Lr} 1, \operatorname{Lr} 16, \operatorname{Lr} 24, \operatorname{Lr} 28, \operatorname{Lr} 17, \operatorname{Lr} 30, \operatorname{Lr} 10, \operatorname{Lr} 14 \mathrm{a}, \operatorname{Lr} 3 \mathrm{bg}$, $L r 14 b, L r 20, L r 13, L r 23, L r 22 \mathrm{~b}$ were found along with Morocco under controlled condition. Overall high frequency of leaf rust phenotypes were identified in limited number of samples. The avirulence/virulence information of $L r$ genes should be utilized in gene deployment and breeding programs, particularly for Sindh province.

Keywords: Wheat, leaf rust, races, virulence.

\section{INTRODUCTION}

Leaf rust (Puccinia triticina) is a foliar disease which significantly reduces wheat (Triticum aestivum L.) production across the globe (Huerta-Espino et al., 2011). Rust epidemics highlight the importance of rust diseases (Boralug, 1968; Bernan, 1994). In Pakistan leaf rust epidemic during 1978 caused 10\% yield loss (Hassan, 1979). Leaf rust prevails throughout the wheat growing areas of Pakistan each year resulting in significant yield losses (Saari and Prescott, 1985).

Being airborne, Puccinia triticina disseminates thousands of kilometers through urediniospore stage (Kolmer and hughes 2015). Due to the polycyclic nature Submitted: November 30, 2020

Revised: December 02, 2020

Accepted for Publication: December 27, 2020

* Corresponding Author: Muhammad Saeed

Email: saeedkalvi114@gmail.com

(C) 2017 Pak. J. Phytopathol. All rights reserved. of the rust, Puccinia triticina has the ability to reproduce asexually and through mutation evolve new virulence phenotypes/races to overcome existing resistant leaf rust genes (McCallum et al., 2016). Therefore, to attain durable rust resistance for long period of time becomes quite difficult task for wheat breeders.

The pathogen's pathotype population can be determined by growing cultivars that have specific pathotype resistance. By inoculating host differential set the virulence pathotypes of rust pathogen can be characterized after few days (Kolmer, 1997). Seedling inoculation of host differentials set not only reduces the inoculum quantity but also limits required space and time. To describe virulence variation, pathotypes geographical distribution and change in pathotypes in response to host can be determined through survey of wheat leaf rust at seedling stage (Ali et al., 2014). In Pakistan on the basis of differential lines effective resistant genes were identified (Hussain et al., 1978). 
Hussain (1979) conducted research work to identify $P$. triticina virulence factors. The studies during 1961-1975 illustrate the prevalence and distribution of 8 P. triticina races in Pakistan. Hence the present study was conducted to check the prevalence and distribution of the P. triticina races in Province Sindh Pakistan.

\section{MATERIALS AND METHODS}

Field scoring and Sample collection: Field scoring of leaf rust was carried out in major wheat growing areas of Sindh. Two parameters were considered in field scoring i.e. severity and host reaction. Modified Cobb scale (0-100 scale) was used to estimate disease severity and percentage of rusted tissue of plant in a field, while considering the field infestation. For revival and race analysis, infected leaf rust samples were collected from different farmer's fields and agriculture farms from February to April during 2017-18 wheat cropping season. The collected samples were dried by placing in closed container containing silica gel.

Revival and race analysis of Leaf rust isolates: Leaf rust urediniospores from individual collection were scraped and 8 to 10 days old susceptible wheat variety "Morocco" seedlings were infected with these urediniospores using wet blotter paper technique. Morocco plants were treated with the solution of maleic hydrazide (MH) at the emergence of coleoptile (Approximately $30 \mathrm{ml} /$ pot). Cyclone spore collectors were used to vacuum the urediniospores into size 00 gel capsules (Browder., 1971). Gel capsule were filled with the solution of petroleum ether and nonphytotoxic paraffinic oil (80:20 ratio) to increase single spore cultures of $P$. triticina on Morocco for the race analysis.

Peat moss was used as potting media to fill the $4 \times 4 \times 4$ $\mathrm{cm}$ plastic pots for sowing leaf rust differential sets. Differential sets were grown in glass house with maintained temperature at $18-22^{\circ} \mathrm{C} .8-10$ days old leaf rust differential seedlings of 26 lines with morocco as susceptible check were inoculated with each single spore leaf rust culture by using fine atomizer. One hour after inoculation the mineral oil was evaporated from the leaves surface and seedlings were shifted to the humid chamber for overnight at $22^{\circ} \mathrm{C}$. The seedlings were then shifted to the clean chamber of glasshouse set at $25^{\circ} \mathrm{C}$ day and $23^{\circ} \mathrm{C}$ night temperature. The data was recorded after 14 days of inoculation at 0-4 scale where infection types 0 to $2^{+}$ were scored as resistant and infection types 3 to 4 were scored as susceptible following method defined by Staakman et al., 1962.

Analysis of data: Five sets of four differentials were used to determine leaf rust races whereas set 6 was sown to check the reaction of particular leaf rust genes against these isolates.

Set $1 \operatorname{Lr} 1, \operatorname{Lr} 2 \mathrm{a}, \operatorname{Lr} 2 \mathrm{c}, \operatorname{Lr} 3$

Set $2 \operatorname{Lr} 9, \operatorname{Lr} 16, \operatorname{Lr} 24, \operatorname{Lr} 26$

Set 3 Lr 3ka, Lr11, Lr17, Lr30

Set4 LrB, Lr10, Lr14a, Lr18

Set5 Lr3Bg, Lr14b, Lr20, Lr19

Set6 Lr13, Lr15, Lr23, Lr27+31, Lr22b, Lr28, Morocco

Every analyzed isolate was assigned a five letter designation based on hexadecimal code adapted for virulence nomenclature of $P$. triticina in North America (Long and Kolmer 1989).

\section{RESULTS AND DISCUSSION}

During 2017-18 wheat cropping season, collection and revival of leaf rust samples from Province Sindh of Pakistan were multiplied and subjected to the virulence analysis. Total 11 isolates were revived resulting in seven different leaf rust pathotypes/races, confirmed on leaf rust differential sets. Pathotype LKTSS found virulent to $L r 1, L r 16, L r 24, L r 26, L r 3 \mathrm{ka}, L r 11, L r 17$, Lr30, LrB, Lr10, Lr14a, Lr3BG, Lr14b, Lr20, Lr13, Lr15, $L r 23$ and $L r 22 \mathrm{~b}$ was the most frequent pathotype at $36.36 \%$ found in 2017-18 leaf rust cultures collection. Pathotype LKFJS virulent to $L r 3, L r 16, L r 24, L r 26, L r 17$, Lr30, Lr10, Lr14a, Lr3BG, Lr14b, Lr20, Lr13, Lr15, Lr23 and $L r 22 \mathrm{~b}$ was the second most common pathotype at $18.18 \%$ found in collection. All remaining pathotypes were found as single culture in collection (Figure 1). All the races were virulent to $\operatorname{Lr} 1, \operatorname{Lr} 16, \operatorname{Lr} 24, \operatorname{Lr} 26, \operatorname{Lr} 30$, Lr10, Lr14a, Lr3bg, Lr14b, Lr20, Lr13, Lr15, Lr23 and $L r 22 \mathrm{~b}$ along with susceptible check morocco. The leaf rust isogenic lines including $\operatorname{Lr} 2 \mathrm{a}, \operatorname{Lr} 9, \operatorname{Lr} 19, \operatorname{Lr} 27+31$ and $\operatorname{Lr} 28$ were found completely resistant to all the inoculated races. The Pathotype PKKSS was the only race that confirmed virulence to gene $L r 2 \mathrm{c}$ whereas gene $L r 2 c$ showed resistance against all remaining races. Similarly, Pathotype MKPSS along with PKKSS found virulent to $L r 3$. All the pathotypes were found virulent to $\operatorname{Lr} 17$ except LKHSS that exhibits low infection type (LIT) on $\operatorname{Lr} 17$. Leaf rust gene $\operatorname{Lr} 18$ found resistant against all races except LKFKS. The response of the isogenic leaf rust differential lines reflected in Figure 2 and the avirulence/virulence of the pathotypes listed in Table 1. LKTSS was the most frequent race observed in current studies and LKTSS isolated from the samples 
of District Mirpur Khas. The second most frequent pathotype LKFJS was isolated from two districts of Sindh i.e. Tando Muhammad Khan and Nausheroferoz. Along with district Mirpur Khas the pathotype LKTSS was also confirmed from the sample of district Omer Kot. Race MKPSS isolated from the samples of district Matiari only. PKKSS, LKHSS and LKKSS were isolated from the samples of district Hyderabad and Nausheroferoz respectively. The districts and virulence of these races were given in Table 1.

In Sindh leaf rust disease of wheat has been reported as one of the major wheat foliar disease (Khan et al., 2020). The leaf rust gene $\operatorname{Lr} 9$ was transferred from Aegilops umbellulatum (Sears,1956) to Chinese spring wheat and its located on chromosome 6B (Sears, 1961). In USA the gene $\operatorname{Lr} 9$ found susceptible in 1971 after four years of its deployment in soft red winter wheat (Shanner et al., 1972). Similar observations were reported from Argentina, Italy (Huerta-Espino 1992) and Brazil. No virulence of $L r 9$ is exists in Pakistan therefore $\operatorname{Lr} 9$ deployment for the improvement of wheat varieties is useful. $\operatorname{Lr} 9$ was postulated in Pakistani Wheat Variety "Marvi" by Rattu, 2006.

In Pakistan virulence for $\operatorname{Lr} 19$ is still absent and it provides excellent barrier in terms of protection. Despite of usage potential for improvement the utilization of Lr19 is limited since its translocation linked with yellow flour pigment (Knott, 1980). Lr19 is positioned on chromosome 7AL and associated with Sr25 (McIntosh et al., 1976 \& Eizenga, 1987). During the current study
Lr19 found completely resistant against all races.

Similar to $\operatorname{Lr} 9$ and $\operatorname{Lr} 19$ the leaf rust gene $L r 28$ also found resistant against all prevailing isolates. Therefore, the incorporation of such resistant genes in national wheat breeding programs plays vital role in disease resistance and ultimately in crop production. Three years studies revealed that $L r 9, L r 19$ and $L r 28$ displayed zero reactions and showed resistance against all prevailing virulence's of leaf rust (Chaudhry et al., 1996) and these outcomes also confirms the recent finding. Due to the frequency of leaf rust resistance genes $\operatorname{Lr} 1$, Lr3, Lr10, Lr13, Lr16 and Lr26 in Pakistani Wheat Commercial varieties the virulence frequency of these were also high (Hussain et al.,1979). Furthermore Mirza et al., (2000) also revealed their occurrence in Pakistani wheat commercial varieties by gene postulation. The leaf rust virulence of commercial varieties like Fakhr-esarhad and Tatara that are growing in northern areas of Pakistan also found in Nawabshah and Karachi (Fayyaz et al., 2008). Therefore, by keeping in view the virulence pattern such wheat commercial should not be permitted to grow in other hot spots. The commercial varieties growing in Sindh including Bakhtawar and Tatara have Lr26 (Rattu, 2006) whereas Sarsabaz caring Lr16 found susceptible to leaf rust (Fayyaz et al., 2008). Lr10 was found susceptible against all races at all districts during current research work and wheat commercial varieties including Auqab-2000, Anmol-91, Zarghoon, Punjab-96, Soghat-90, Margalla-99, Chakwal-86 and Inqilab-91 contains Lr10 in its blood line.

Table 1. Avirulence/Virulence patterns of Puccinia triticina races

\begin{tabular}{|c|c|}
\hline Race & Avirulence/Virulence \\
\hline MKPSS & $\begin{array}{l}\text { Lr2a, Lr2c, Lr9, Lr11, Lr18, Lr19, Lr27+31, Lr28/ Lr1, Lr3, Lr16, Lr24, Lr26, Lr3ka, Lr17, Lr30, LrB, } \\
\text { Lr10, Lr14a, Lr3bg, Lr14b, Lr20, Lr13, Lr15, Lr23, Lr22b }\end{array}$ \\
\hline LKTSS & $\begin{array}{l}\text { Lr2a, Lr2c, Lr3, Lr9, Lr18, Lr19, Lr27+31, Lr28/ Lr1, Lr16, Lr24, Lr26, Lr3ka, Lr11, Lr17, Lr30, LrB, } \\
\text { Lr10, Lr14a, Lr3bg, Lr14b, Lr20, Lr13, Lr15, Lr23, Lr22b }\end{array}$ \\
\hline LKFKS & $\begin{array}{l}\text { Lr2a, Lr2c, Lr3, Lr9, Lr3ka, Lr11, LrB, Lr19, } \operatorname{Lr} 27+31, \operatorname{Lr} 28 / \operatorname{Lr} 1, \operatorname{Lr} 16, \operatorname{Lr} 24, \operatorname{Lr} 26, \operatorname{Lr} 17, \operatorname{Lr} 30, \operatorname{Lr} 10, \\
\operatorname{Lr14a}, \operatorname{Lr} 18, \operatorname{Lr} 3 b g, \operatorname{Lr} 14 b, \operatorname{Lr} 20, \operatorname{Lr} 13, \operatorname{Lr} 15, \operatorname{Lr} 3, \operatorname{Lr} 22 b\end{array}$ \\
\hline LKKSS & $\begin{array}{l}\text { Lr2a, Lr2c, Lr3, Lr9, Lr3ka, Lr18, Lr19, Lr27+31, Lr28/ Lr1, Lr16, Lr24, Lr26, Lr11, Lr17, Lr30, LrB, } \\
\text { Lr10, Lr14a, Lr3bg, Lr14b, Lr20, Lr13, Lr15, Lr23, Lr22b }\end{array}$ \\
\hline PKKSS & $\begin{array}{l}\text { Lr2a, Lr9, Lr3ka, Lr18, Lr19, Lr15, Lr27+31, Lr28/ Lr1, Lr2c, Lr3, Lr16, Lr24, Lr26, Lr11, Lr17, Lr30, } \\
\text { LrB, Lr10, Lr14a, Lr3bg, Lr14b, Lr20, Lr13, Lr23, Lr22b }\end{array}$ \\
\hline LKFJS & $\begin{array}{l}\text { Lr2a, } \operatorname{Lr} 2 c, \operatorname{Lr} 3, \operatorname{Lr} 9, \operatorname{Lr} 3 k a, \operatorname{Lr} 11, \operatorname{Lr} B, \operatorname{Lr} 18, \operatorname{Lr} 19, \operatorname{Lr} 27+31, \operatorname{Lr} 28 / \operatorname{Lr} 1, \operatorname{Lr} 16, \operatorname{Lr} 24, \operatorname{Lr} 26, \operatorname{Lr} 17, \operatorname{Lr} 30, \\
\operatorname{Lr10}, \operatorname{Lr} 14 a, \operatorname{Lr} 3 b g, \operatorname{Lr} 14 b, \operatorname{Lr} 20, \operatorname{Lr} 13, \operatorname{Lr} 15, \operatorname{Lr} 23, \operatorname{Lr} 22 b\end{array}$ \\
\hline LKHSS & $\begin{array}{l}\text { Lr2a, Lr2c, Lr3, Lr9, Lr3ka, Lr17, Lr18, Lr19, Lr27+31, Lr28/ Lr1, Lr16, Lr24, Lr26, Lr11, Lr30, LrB, } \\
\text { Lr10, Lr14a, Lr3bg, Lr14b, Lr20, Lr13, Lr15, Lr23, Lr22b }\end{array}$ \\
\hline
\end{tabular}




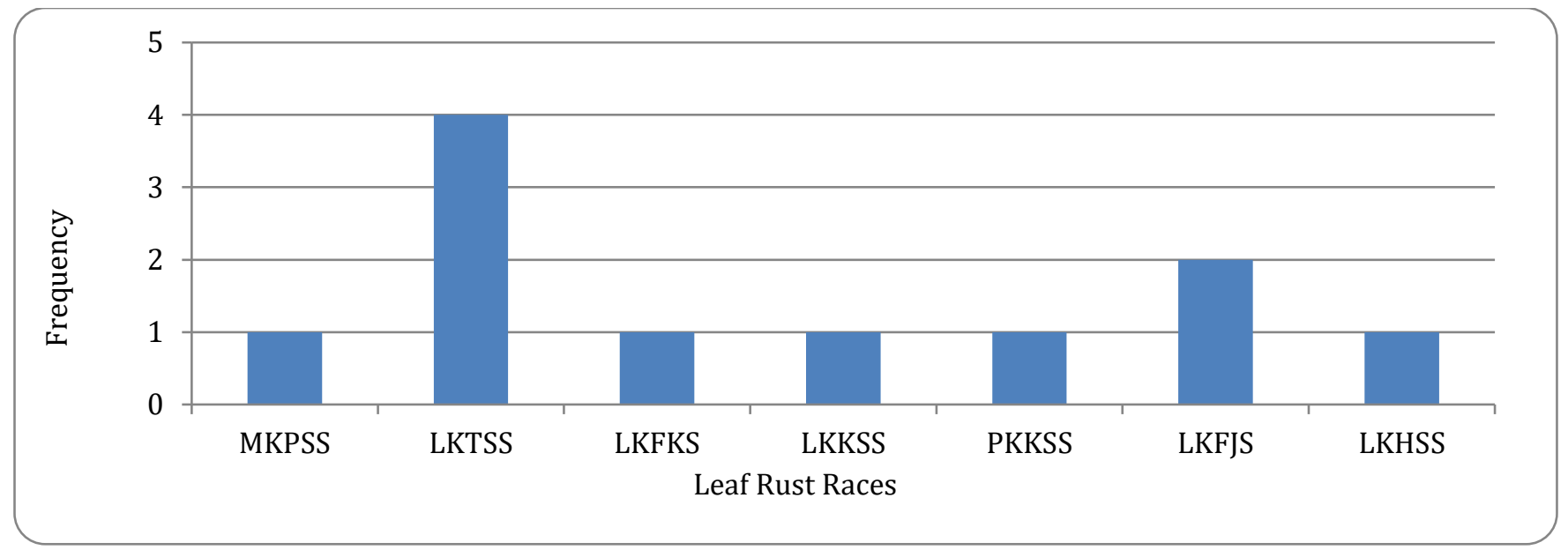

Figure1: Leaf Rust races frequency.

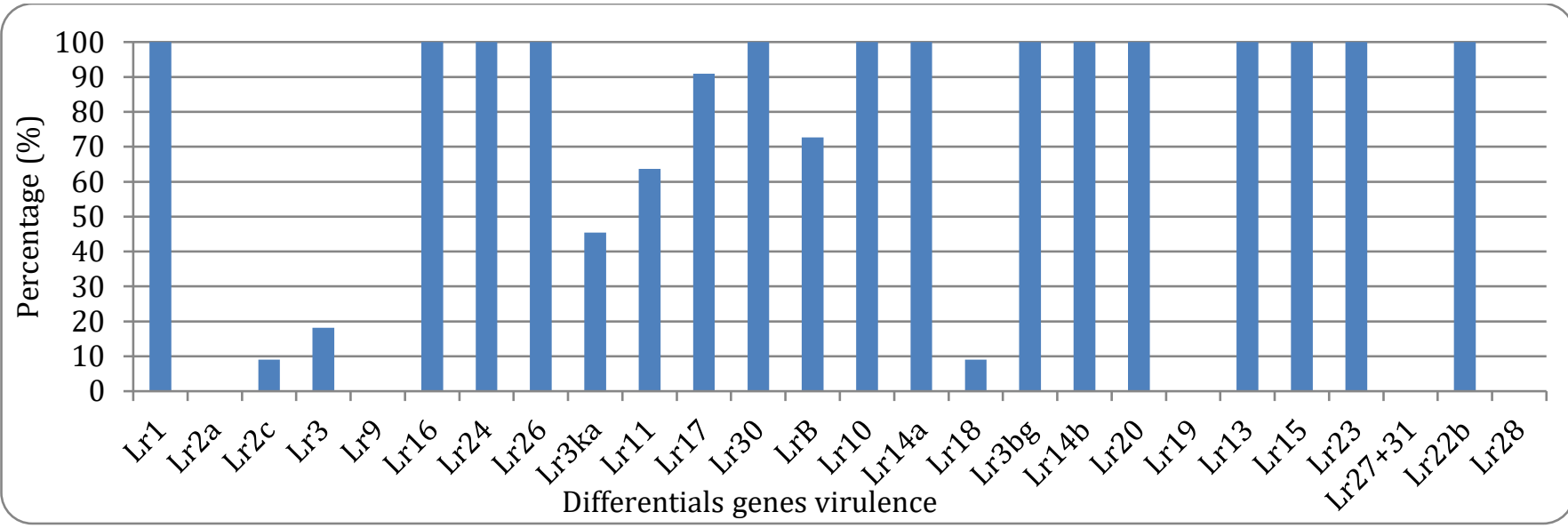

Figure2. Differentials genes virulence against different races.

The major wheat variety inqilab-91 contains the genes Lr10, $27+31$ beside this its parental pedigree also have Crow and WL-711 the adult plant resistance (APR) that shows slow rusting behavior. Therefore, by keeping in view the virulence of $\operatorname{Lr} 10$ for future wheat breeding the leaf rust gene Lr10 should very carefully be selected. Lr13 gene associated to Lr23 (McIntosh et al., 1995) is responsible for adult plant resistance (APR) whereas at seedling stage it's a temperature sensitive gene. $\operatorname{Lr} 13$ is present in MH-97, Sairab-92, Wafaq-2001, Parwaz-94, Haider-2000 and Zarlashta. Lr26 presents as the dominant gene in various spring and winter wheat genetically associated to $\mathrm{Sr} 31, \mathrm{Pm} 8$ and $\mathrm{Yr} 9$ (Mclntosh et al., 1995) is becoming ineffective. Due to Lr26 presence and the high virulence it had serious impact on wheat production worldwide. As CIMMYT is the key source of wheat germplasm with the dominant genes including Lr1, Lr3, Lr10, Lr13, Lr16, Lr23, Lr26 and Gatcher therefore our common wheat commercial varieties claimed these genes in their background (Mirza et al., 2000).

\section{REFERENCES}

Ali, S., P. Gladieux, M. Leconte, A. Gautier, A.F. Justesen, M.S. Hovmoller. 2014. Origin, migration routes and worldwide population genetic structure of the wheat yellow rust Puccinia striiformis $f$. sp trirtici. PLoS Pathog 10Article e1003903.

Borlaug, N.E. 1968. Wheat breeding and its impact on world food supply. Third International Wheat Genetics Symposium, 5-9 August, Canberra, Australia.

Brennan, J.P., G.M. Murray and B.J. Ballantyne. 1994. Assessing the economic importance of disease resistance in wheat. NSW Agriculture, Agricultural Research Institution, Waga. Final Report of the Grains Research and Development Corporation, 
Australia.

Browder, L.E. 1971. Pathogenic Specialization in Cereal Rust Fungi, Especially Puccina recondite $f$. $s p$. Tritici: Concepts, Methods of Study, and Application. U.S. Dep. Agric. Tech. Bull. No. 1432.

Chaudhry, M.H., M. Hussain and J.A. Shah. 1996. Wheat rust scenario, 1994-1995. Pak. J.Phytopathology, 8: 96-100.

Eizenga, G.C. 1987. Locating the Agropyron segment in wheat-Agropyron transfer no.12.Genome, 29: 365366.

Fayyaz, M., A.R. Rattu, I. Ahmad, M.A. Akhtar, A.A. Hakro and A. Mujeeb-Kazi. 2008. Current status of the occurrence and distribution of (Puccinia triticina) wheat leaf rust virulence in Pakistan. Pak. J. Bot., 40(2): 887-895.

Hassan, S.F. 1979. Wheat disease situation in Pakistan. Paper presented in National Seminar on Wheat research and production, 6 Aug.1979. Islamabad.

Huerta-Espino, J. 1992. Analysis of wheat leaf and stem rust virulence on worldwide basis. Ph.D. Thesis, University of Minnesota, Minnesota, U.S.A

Huerta-Espino, R.P. Singh, S. German. 2011. Global status of wheat leaf rust caused by Puccinia triricina. Euphytica, 179 pp. 143-160.

Hussain, M., S.F. Hassan and M.S.A. Kirmani. Virulences in Puccinia recondita Rob. Ex Desm. f.sp. tritici in Pakistan during 1978 and 1979. Proceedings of the fifth European and Mediterranean cereal rusts conference, Bari, Italy, 179-184.

Khan M. R., M. Imtiaz, I. Munir, I. Hussain and S, Ali. 2020. Differential distribution of leaf rust across major wheat growing regions of Pakistan revealed through a three year surveillance effort. Pak. J. Bot., 53(1).

DOI: http://dx.doi.org/10.30848/PJB2021-1 (21).

Knott, D.R. 1980. Mutation of a gene for yellow pigment linked to Lr19 in wheat. Canadian J. Genetics and Cytology, 22: 651-654.

Kolmer, J.A. 1997. Virulence in Puccinia recondita f.sp. tritici isolates from Canada to genes for adult plant resistance to wheat leaf rust. Plant Dis., 81: 267 271.
Kolmer, J.A., and M. E. Hughes. 2015. Pysiological specialization of Puccinia triticina on wheat in the United States in 2013. Plant Dis. 99:1261-1267.

Long, D. L., and J. A. Kolmer. 1989. A North American system of nomenclature for Puccina recondite f. $s p$. Tritici. Phytopathology, 79:525-529.

McCallum, B.D. C.W. Hiebert, S. Cloutier. 2016. A review of wheat leaf rust research and development of resistant cultivars in Canada. Can. J. Plant Pathol, 38pp.1-18.

McIntosh R.A., P.L. Dyck and G.J. Green. 1976. Inheritance of leaf and stem rust resistance in wheat cultivars Agent and Agatha. Australian J. of Agricultural Research, 28: 37-45.

Mirza, J.I., R.P. Singh and I. Ahmad. 2000. Resistance to leaf rust in Pakistani wheat lines. Pakistan Journal of Biological Sciences, 3: 1056-1061.

Rattu, A.R. 2006. Virulence analysis of Puccinia triticina population and gene postulation in current genotypes of wheat against leaf rust. Ph. D Thesis, Department of Plant Pathology, University of Arid Agriculture Rawalpindi, Pakistan.

Saari, E. E., and J. M. Prescott. 1985. World distribution in relation to economic losses. Pages 259-298 in: The Cereal Rusts, Vol. II. Diseases, Distribution, Epidemiology and Control. A. P. Roelfs and W. R. Busnell, eds. Academics Press, Orlando, FL.

Sears, E.R. 1956. The transfer of leaf-rust resistance from Aegilops umbellulata to wheat. Brookhaven Symposia in Biology, 9: 1-22.

Sears, E.R. 1961. Identification of the wheat chromosome carrying leaf rust resistance genes from Aegilops umbellulata. Wheat Information Service, 12: 12-13.

Shanner, G., J.J. Roberts and R.E. Finney. 1972. A culture of Puccinia recondita virulent to the wheat cultivar Transfer. Plant Disease Reporter, 56: 827-830.

Stakman, E. C., D. M. Stewart and W. O. Loegering, 1962. Identification of physiologic races of Puccina graminis var, tritici. U.S. Dep. Agric. Agric. Res. Serv., E-617. 53pp.

Stakman, E.C. 1919. New biologic forms Puccinia graminis. J. Agric. Res., 16: 103-105.

Contribution of Authors:

All authors contributed equally in the research work and writing this manuscript. 